\title{
ANALISA PENGARUH RELATIONSHIP MARKETING TERHADAP LOYALITAS NASABAH PADA PT. BANK PERKREDITAN RAKYAT SEGARA ANAK KENCANA CABANG MATARAM
}

\author{
Linda Maya Sastra1, Dwi Putra Buana Sakti ${ }^{2}$, L.M Furkon ${ }^{3}$ \\ 1Program Studi Magister Manajemen Fakultas Ekonomi dan Bisnis Unram \\ Email :sastramayaa1@gmail.com \\ 2Fakultas Ekonomi dan Bisnis Unram, Email : dwiputrabs39@gmail.com \\ ${ }^{3}$ Fakultas Ekonomu dan Bisnis Unram, Email : lalu.furkan@gmail.com
}

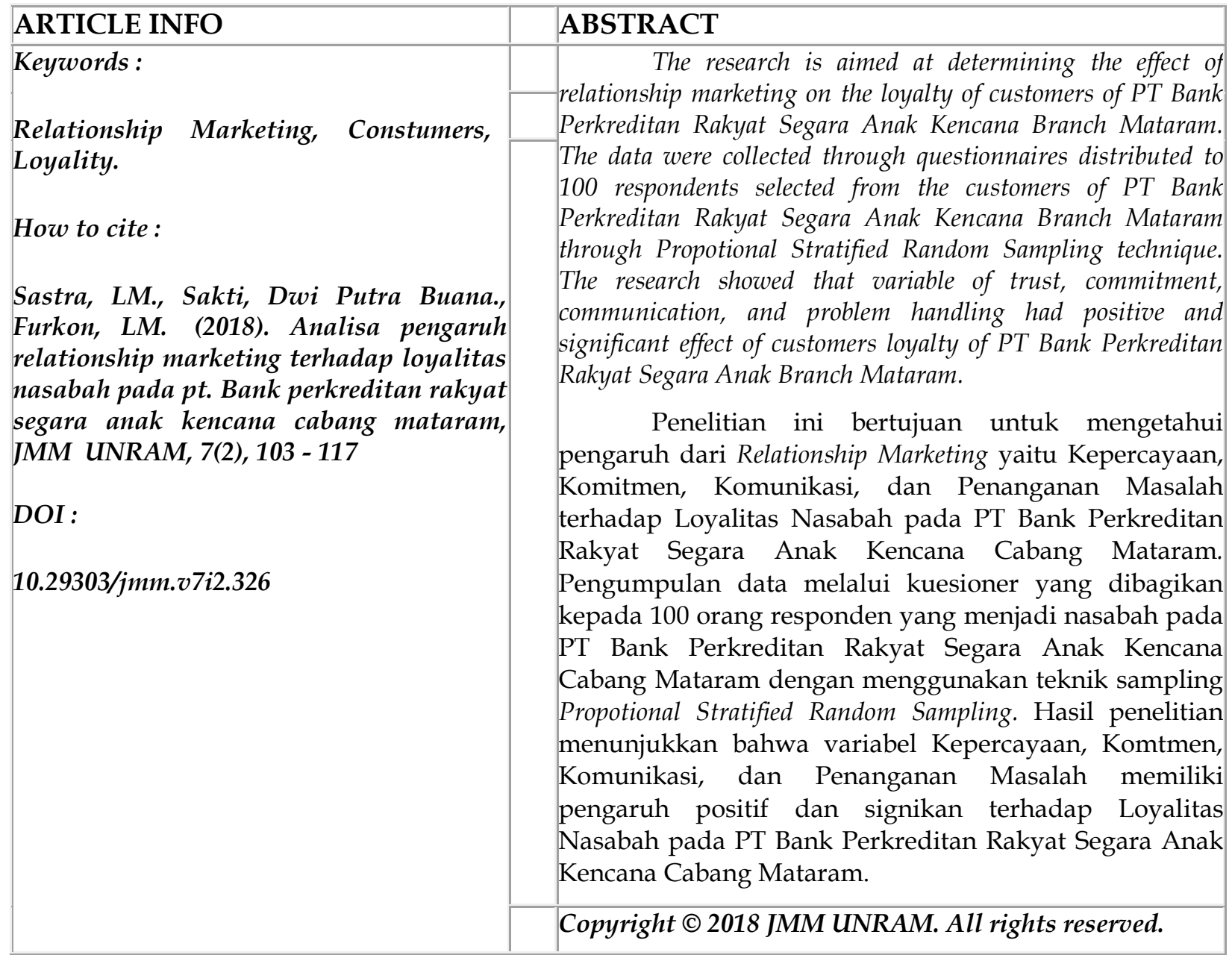




\section{PENDAHULUAN}

Loyalitas didefinisikan sebagai komitmen pelanggan untuk bertahan secara mendalam untuk berlangganan kembali atau melakukan pembelian ulang produk atau jasa terpilih secara konsiten dimasa yang akan datang, meskipun pengaruh situasi dan usaha-usaha pemasaran mempunyai potensi untuk menyebabkan perilaku (Oliver,1997). Beberapa perusahaan menerapakan beberapa strategi yang dapat digunakan dalam menciptakan loyalitas konsumen, salah satunya adalah Relationship Marketing. Strategi Relationship Marketing didefinisikan sebagai seluruh kegiatan pemasaran dalam membangun, mengembangkan dan mempertahankan hubungan pertukaran yang sukses, (Morgan and Hunt, 1994 dalam Sulhaini 2014).

Penelitian terdahulu memiliki hasil yang berbeda dalam mengetahui Loyalitas Konsumen dengan menerapkan variabel Relationship Marketing. Penelitian yang dilakukan oleh Ndubisi (2007), Hussnain dan Akhtar (2017) dan Suparwata (2017) dengan menggunakan empat dimensi Relationship marketing menyatakan bahwa memiliki pengaruh positif dan signifikan terhadap loyalitas konsumen. Penelitian yang dilakukan oleh Adjei dan Clark (2010),Abtin dan Pouramiri (2015), Yoganathan et al (2015), Karjaluoto et al (2016), Ansari dan Riasi (2016), Lee et al (2017) dengan menggunakan lebih dari empat dimensi yang termasuk dalam Relationship marketing memberikan hasil positif dan signifikan terhadap loyalitas nasabah.

Namun, perbedaan hasil juga ditunjukkan dalam beberapa penelitian terdahulu yang dilakukan oleh Jumaev (2012) menyatakan bahwa variabel kepercayaan (trust) tidak berpengaruh terhadap loyalitas, penelitian Semuel (2012) memberikan hasil bahwa variabel kepercayaan,komitmen dan komunikasi tidak berpengaruh terhadap loyalitas. Penelitian lainnya yang dilakukan oleh Bressan (2014) yang melihat pengaruh variabel Realtionship marketing seperti kepercayaan (trust), komitmen dan culture (budaya) negara setempat dalam usaha berkembang di India menyatakan bahwa tidak memiliki pengaruh. Serta penelitian yang Bilgihan dan Bujisic (2015) menyatakan bahwa variabel Komitmen tidak berpengaruh terhadap Loyalitas.

Dalam usaha perbankan, diperlukan strategi khusus oleh perusahaan dalam menciptakan loyalitas. Ini dikarenakan tingkat interaksi antara Bank dengan nasabah begitu intens dilakukan yang berkaitan dengan pelayanan. Bank Perkreditan Rakyat Segara Anak Kencana dibuka secara resmi pada tanggal 4 April 1990 berlokasi di Kecamatan Aikmel Kabupaten Lombok Timur dengan membangun visi dan misi menyediakan berbagai layanan perbankan mulai dari tabungan, deposito dan kredit atau layanan simpan pinjam yang berorientasi ke usaha kecil dan menenengah. Beberapa keunggulan yang diberikan oleh Bank Perkreditan Rakyat Segara Anak Kencana Cabang Mataram adalah mulai dari kemudahan dalam proses pembayaran angsuran kredit, suku bunga yang flat setiap bulannya serta kemudahan dalam setiap proses transaksi perbankan lainnya. Namun, Bank Perkreditan Rakyat Segara Anak Kencana Cabang Mataram ini pernah mengalami penurunan jumlah nasabah yang terjadi pada tahun 2014 dan dalam kurun waktu 2011-2015 juga mengalami kenaikan persentase dari nasabah yang tutup buku atau keluar dari Bank Perkreditan ini. Berdasarkan latar belakang tersebut, maka dilakukan penelitian untuk mengetahui tingkat loyalitas nasabah pada Bank Perkreditan Rakyat Segara Anak Kencana Cabang Mataram 
dengan penerapan strategi Relationship Marketing yang berfokus pada empat elemen yaitu Kepercayaan (Trust), Komitmen, Komunikasi, dan Penanganan Masalah.

\section{KERANGKA KONSEPTUAL PENELITIAN}

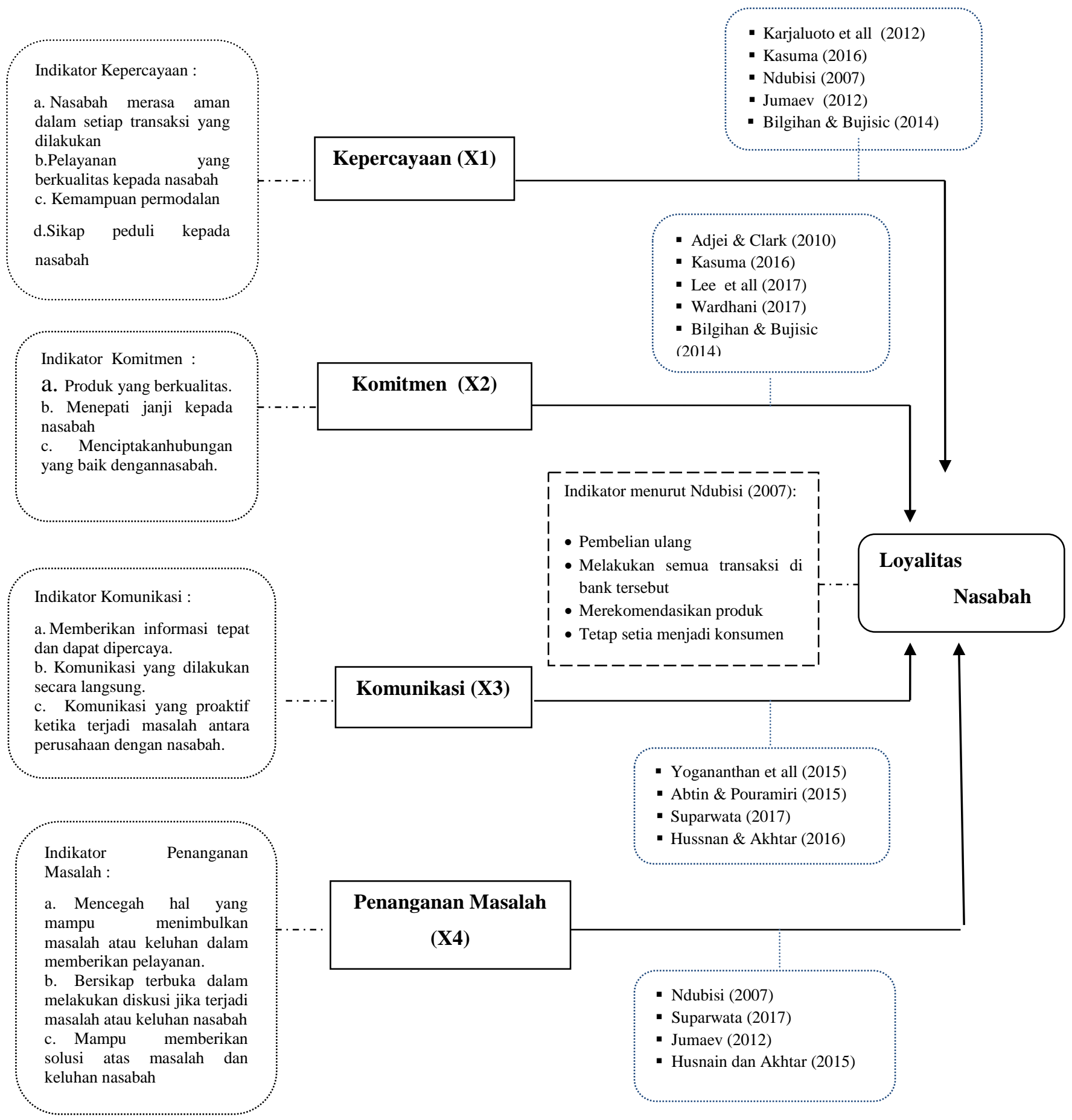




\section{KAJIAN PUSTAKA}

\subsection{LOYALITAS}

Loyalitas

Loyalitas konsumen secara harfiah diartikan sebagai kesetiaan, yaitu kesetiaan seseorang terhadap suatu objek.Kesetiaan ini timbul tanpa adanya suatu paksaan, tetapi timbul dari kesadaran diri pada masa lalu (Zain, 2013). Loyalitas menurut Tjiptono (2001) didefinisikan sebagai situasi dimana konsumen bersikap positif terhadap produk atau produsen (penyedia jasa) dan disertai pola pembelian berulang yang konsisten. Definisi lain menurut Oliver ( dalam Hurriyati, 2008:128) adalah komitmen pelanggan untuk bertahan secara mendalam untuk berlangganan kembali atau melakukan pembelian ulang produk atau jasa terpilih secara konsisten dimasa yang akan datang, meskipun pengaruh situasi dan usahausaha pemasaran mempunyai potensi untuk menyebabkan perubahan perilaku. Sementara menurut Griffin (2002: 4) Loyalitas lebih mengacu pada wujud perilaku dari unit-unit pengambilan keputusan untuk melakukan pembelian secara terus menerus terhadap barang atau jasa suatu perusahaan yang dipilih. Beberapa keuntungan yang diperoleh oleh perusahaan apabila memiliki pelanggan yang loyal menurut Griffin (2002) adalah mulai dari mengurangi biaya pemasaran untuk menarik pelanggan baru, mengurangi biaya transaksi, mengurangi biaya turn over konsumen, dan mampu mendorong word of mouth yang lebih positif, dengan asumsi bahwa pelanggan yang loyal juga berarti mereka yang merasa puas.

\subsection{RELATIONSHIP MARKETING}

\subsubsection{Definisi Relationship Marketing}

Dalam Abdullah (2014), Morgan dan Hunt (1994) mendefinisikan Relationship marketing sebagai seluruh kegiatan pemasaran yang diarahkan kepada membangun, mengembangkan dan mempertahankan hubungan pertukaran yang sukses. Teori Relationship marketing menjelaskan perkembangan hubungan dengan mitra atau konsumen yang menuntut aktifitas membangun hubungan yang harus dilakukan oleh kedua belah pihak (Sulhaini, 2014).

Beberapa peneliti memberikan definisi dari Relationship Marketing (RM) seperti dibawah ini :

1. Relationship Marketing is an important topic in marketing theory because of its crucial role in helping develop and maintain mutually develop and sustainable relationship among buyer and sellers ( Lee et al, 2015).

2. Relationship Marketing as a strategic alternative to the traditional marketing approach with the power to enhance the dynamics interactions in firm's relationship with customers (Gronroos ,1994 dalam Shalaan et al,2015).

3. Relationship Marketing has shifted the focus of marketing orientation from attracting short term and discrete transactional customer towards retaining loyal customer (Taleghani et al,2011 dalam Yoganathan et al,2015).

Relationship marketing merupakan suatu praktik membangun hubungan jangka panjang yang memuaskan dengan pihak-pihak kunci yang meliputi pelanggan, pemasok, penyalur dan beberapa rekan usaha lainnya guna mempertahankan preferensi dan bisnis jangka panjang 
(Kotler, 2007). Mengingat bank merupakan sebuah usaha dengan tingkat interaksi dan pelayanan kepada konsumen dalam hal ini nasabah tergolong tinggi, maka Relationship marketing menjadi salah satu strategi yang efektif untuk membangun hubungan jangka panjang dengan nasabah (So dan Speece,2000 dalam Yoganathan et al 2015). Menurut Kotler dan Keller (2008) tujuan Relationship marketing adalah mengembangkan hubungan yang dalam dan bertahan lama dengan orang dan organisasi yang dapat secara langsung maupun tidak langsung mempengaruhi kesuksesan aktifitas pemasaran perusahaan tersebut.

\subsubsection{Elemen-elemen Relationship marketing}

1. Kepercayaan (Trust)

Kepercayaan merupakan variabel kunci dalam pengembangan keinginan yang kuat untuk mempertahankan sebuah hubungan jangka panjang. Untuk dapat mempertahankan loyalitas, perusahaan tidak hanya mengandalkan pada kepuasan yang dirasakan oleh pelanggan, tetapi lebih dari itu bahwa kepercayaan merupakan perantara kunci dalam membangun keberhasilan pertukaran hubungan untuk membangun loyalitas pelanggan yang tinggi..Tanpa adanya kepercayaan suatu hubungan tidak akan bertahan dalam jangka panjang (Karjaluoto et al, 2012).Kepercayaan merupakan faktor terbentuknya loyalitas konsumen karena loyalitas konsumen mencakup faktor-faktor kepercayaan dan pengorbanan (Lee et al, 2017).

\section{Komitmen}

Komitmen menjadi hal yang mendasar dalam menciptakan kepuasan pada konsumen dan mampu menumbuhkan loyalitas ( Ansari dan Riasi,2016). Komitmen didefinisikan sebagai cara lain untuk menyampaikan aspirasi untuk mempertahankan sebuah hubungan (Morgan \& Hunt,1994 dalam Kasuma 2016). Komitmen dan kepercayaan menjadi dua hal yang mempengaruhi dalam Relationship marketing.Kedua faktor ini menjadi elemen penting guna menjamin keberlangsungan hubungan bisnis dalam waktu lama dimana hal tersebut menjadi poin penting dalam menimplementasikan Relationship marketing itu sendiri.Komitmen perusahaan dapat diperoleh dengan cara perusahaan menjadikan pelanggan sebagai prioritas utama, berjangka panjang, dan berdasarkan pada hubungan yang saling menguntungkan. Komitmen perusahaan juga dapat diartikan sebagai janji atau ikrar perusahaan untuk memelihara hubungan yang telah terjalin dengan baik, karena hubungan tersebut memiliki arti penting (Ndubisi,2011).

\section{Komunikasi}

Komunikasi menjadi sangat penting karena sebuah hubungan tidak dapat dimulai tanpa adanya komunikasi.Komunikasi memiliki arti sebagai kemampuan untuk menydiakan informasi yang tepat dan akurat. Dalam konteks relationship marketing, komunikasi berarti tetap menjalin hubungan atau melakukan keeping touch kepada konsumen tentang produk perusahaan yang telah digunakan oleh konsumen, bisa juga memberikan pertanyaan ringan tentang pendapat konsumen mengenai pelayanan yang telah diterima setelah melakukan transaksi pada perusahaan tersebut. 


\section{Penanganan Masalah}

Dalam setiap hubungan sosial maupun ekonomi selalu terdapat rasa saling ketergantungan diantara semua pihak. Perusahaan dan pelanggan yang saling bergantung harus dapat menciptakan hubungan yang saling mendukung satu sama lain, namun pada kenyataanya hubungan yang saling bergantung tersebut dapat menciptakan konflik yang disebabkan oleh berbagai macam hal. Kemampuan penanganan konflik mengacu pada kemampuan perusahaan untuk mencegah atau meminimalkan dampak dari hal-hal yang potensial dapat menimbulkan konflik, dan kemampuan menyelesaikan konflik nyata yang sudah terjadi. Penanganan konflik merupakan tindakan khusus pada saat melakukan interaksi dengan pelanggan (Ball et al., 2004). Kemampuan pihak perusahaan dalam menangani konflik dengan baik akan memberikan kepuasan pada pelanggan dan menyebabkan pelanggan menjadi loyal (Ndubisi, 2007).

\subsubsection{Hubungan antar variabel dan Hipotesa Penelitian}

1). Berdasarkan pada tinjauan teori dan penelitian terdahulu yang dinyaatakan pada pendahuluan dariNdubisi (2007), Karjaluoto et all (2012), Kasuma (2016), dan Bilgihan \& Bujisic (2014), Yoganathan et al (2015) menyebutkan bahwa variabel Kepercayaan (trust) berpengaruh signifikan terhadap loyalitas konsumen, maka peneliti menyatakan hipotesis berikut : Diduga terdapat pengaruh kepercayaan terhadap Loyalitas Nasabah, semakin tinggi kepercayaan semakin tinggi loyalitas (H1).

2). Berdasarkan tinjauan teori dan beberapa hasil studi empiris penelitian terdahulu dari Adjei \& Clark (2010), Kasuma (2016) , Lee et all (2017), Ansari dan Riasi (2016) dan Wardhani (2017) menyatakan bahwa variabel komitmen memiliki pengaruh signifikan terhadap loyalitas konsumen, maka peneliti menyatakan hipotesis berikut : Diduga terdapat pengaruh komitmen terhadap Loyalitas Nasabah, semakin tinggi komitmen semakin tinggi loyalitas (H2).

3). Berdasarkan tinjauan teori dan beberapa hasil studi empiris penelitian terdahulu yang dinyata dariYoganathan et al (2012), Abtin dan Poramiri (2015), Husnain dan Akhtar (2015) dan Suparwata (2017) menyatakan bahwa variabel komunikasi memiliki pengaruh signifikan terhadap loyalitas konsumen, maka peneliti menyatakan hipotesis berikut : Diduga terdapat pengaruh Komunikasi terhadap Loyalitas Nasabah, semakin baik komunikasi semakin tinggi Loyalitas (H3).

4). Berdasarkan tinjauan teori dan beberapa hasil studi empiris sebagaimana dinyatakan pada penelitian terdahulu dari Ndubisi (2011), Hussnain dan Akhtar (2015), Jumaev (2012) dan Suparwata (2017) menyatakan bahw variabel penanganan masalah memiliki pengaruh signifikan terhadap Loyalitas konsumen, maka peneliti menyatakan hipotesis berikut : Diduga terdapat pengaruh Penanganan masalah terhadap Loyalitas, semakin baik penanganan masalah semakin tinggi Loyalitas $(\mathrm{H} 4)$. 


\section{METODE PENELITIAN}

\subsection{Jenis Penelitian}

Jenis penelitian ini merupakan penelitian kuantitatif assosiatif. Penelitian asosiatif merupakan penelitian yang bertujuan untuk mengetahui pengaruh satu variabel terhadap variabel yang lain. Melalui penelitian ini akan membuktikan hubungan dan pengaruh antar variabel dan diharapkan akan memberikan rumusan untuk menemukan pengaruh dari Relationship marketing terhadap Loyalitas Nasabah Pada PT. Bank Perkreditan Rakyat Segara Anak Kencana Cabang Mataram.

\subsection{Lokasi Penelitian}

Penelitian dilakukan di PT Bank Perkreditan Rakyat Segara Anak Kencana Cabang Mataram.

\subsection{Metode Pengumpulan Data}

Metode pengumpulan data yang digunakan dalam penelitian adalah dengan menggunakan metode survey.

\subsection{Penentuan Responden}

Sugiyono (2006) mengemukakan "Populasi adalah wilayah generalisasi yang terdiri atas obyek/subyek yang mempunyai kualitas dan karakteristik tertentu yang ditetapkan peneliti yang kemudian ditarik kesimpulannya". Populasi dari penelitian ini adalah nasabah pada Bank Perkreditan Rakyat Segara Anak Kencana Cabang Mataram. Dengan menggunakan metode "Propotional stratified random sampling" diperoleh jumlah sampel yaitu 100 orang responden yang dibagi berdasarkan jenis nasabah kredit, tabungan, dan deposito. Metode "Systematica Sampling" digunakan untuk mengetahui titik awal dalam penentuan responden masing-masing kategori tersebut.

\subsection{Teknik dan Alat Pengumpulan Data}

Teknik pengumpulan data adalah bagian dari instrument pengumpulan data yang menentukan keberhasilan tujuan suatu penelitian (Bungin,2009). Teknik pengumpulan data yang digunakan dalam penelitian ini adalah :

1. Teknik Dokumentasi

Teknik dokumentasi yaitu teknik pengumpulan data dengan cara melakukan pengutipan dari dokumen yang ada di objek penelitian.

2. Teknik Angket

Teknik angket merupakan teknik pengumpulan data yang dilakukan dengan cara memberi seperangkat pertanyaan atau pernyataan tertulis kepada responden untuk dijawab.

\section{Wawancara}

Teknik wawancara yaitu pengambilan informasi dengan melakukan tanya jawab secara langsung terhadap responden yang telah ditentukan. 


\subsection{Jenis dan Sumber Data}

\subsubsection{Jenis Data}

Jenis data yang digunakan dalam penelitian ini adalah data kuantitatif dan data kualitatif. Data kuantitatif adalah data yang yang ditampilkaan dalam bentuk angka-angka, sedangkan data kualitatif adalah data berbentuk uraian atau penjelasan yang berhubungan dengan penelitian ini.

\subsubsection{Sumber Data}

Sumber data penelitian ini dikumpulkan dari data primer yang merupakan data yang diperoleh secara langsung dan bersumber dari responden melalui hasil pengisian kuesioner. Dan sumber data sekunder adalah data yang diperoleh dari data pendukung seperti dari perusahaan tempat melakukan penelitian ataupu literature yang berhubungan dengan penelitian.

\section{HASIL DAN PEMBAHASAN}

\subsection{Deskripsi Hasil Penelitian}

\subsubsection{Karakteristik Responden}

\begin{tabular}{|c|c|c|}
\hline NO & KATEGORI & JUMLAH \\
\hline 1 & $\begin{array}{l}\text { Jenis Kelamin : } \\
\text { - } \quad \text { Laki-laki } \\
\text { - } \quad \text { Perempuan }\end{array}$ & $\begin{array}{l}46 \% \\
54 \%\end{array}$ \\
\hline 2 & $\begin{array}{l}\text { Umur: } \\
\text { - } \quad<31 \text { Tahun } \\
\text { - } \quad 31-40 \text { Tahun } \\
\text { - } \quad>40 \text { Tahun }\end{array}$ & $\begin{array}{l}15 \% \\
63 \% \\
22 \%\end{array}$ \\
\hline 3 & $\begin{array}{ll}\text { Tingkat Pendidikan: } \\
\text { - } & \text { SMP } \\
\text { - } & \text { SMA } \\
\text { - } & \text { DIPLOMA } \\
\text { - } & \text { S1 } \\
\text { - } & \text { S2 }\end{array}$ & $\begin{array}{c}21 \% \\
54 \% \\
10 \% \\
7 \% \\
8 \%\end{array}$ \\
\hline 4 & $\begin{array}{l}\text { Pekerjaan: } \\
\text { - } \quad \text { Pelajar/Mahasiswa } \\
\text { - } \quad \text { PNS } \\
\text { - TNI/POLRI } \\
\text { - Wiraswasta } \\
\text { - } \quad \text { Pegawai Swasta }\end{array}$ & $\begin{array}{c}6 \% \\
16 \% \\
15 \% \\
43 \% \\
20 \%\end{array}$ \\
\hline 5 & $\begin{array}{l}\text { Pendapatan: } \\
\text { - } \quad<1,5 \text { Juta } \\
\text { - } \quad 1,5-2,5 \text { Juta } \\
\text { - } \quad>2,5 \text { Juta }\end{array}$ & $\begin{array}{r}8 \% \\
42 \% \\
50 \%\end{array}$ \\
\hline 6 & $\begin{array}{l}\text { Lama Menjadi Nasabah: } \\
\text { - } \quad<1 \text { Tahun } \\
\text { - } \quad 1-5 \text { Tahun } \\
\text { - } \quad>5 \text { Tahun }\end{array}$ & $\begin{array}{r}8 \% \\
42 \% \\
50 \%\end{array}$ \\
\hline
\end{tabular}




\subsection{Deskripsi Variabel Penelitian}

\begin{tabular}{|c|c|c|c|}
\hline NO & $\begin{array}{c}\text { VARIABEL BEBAS } \\
\text { VARIABEL TERIKAT }\end{array}$ & INDIKATOR & KATEGORI \\
\hline 1 & Kepercayan (X1) & $\begin{array}{l}\text { - Nasbahmerasa aman dalam bertransaksi } \\
\text { - Pelayanan yang berkualitas } \\
\text { - Kemampuan permodalan } \\
\text { - Menunjukkan sikap peduli kepada } \\
\text { nasabah. }\end{array}$ & Tinggi \\
\hline 2 & Komitmen (X2) & $\begin{array}{l}\text { - } \text { Produk yang berkualitas } \\
\text { - Memenuhi janji kepada nasabah } \\
\text { - Menciptakan hubungan yang baik } \\
\text { dengan nasabah }\end{array}$ & Efektif \\
\hline 3 & Komunikasi (X3) & $\begin{array}{l}\text { - Bank memberikan informasi yang tepat } \\
\text { dan dapat dipercaya } \\
\text { - Komunikasi secara langsung dengan } \\
\text { nasabah } \\
\text { - Komunikasi yang proaktif ketika terjadi } \\
\text { masalah }\end{array}$ & Efektif \\
\hline 4 & Penanganan Masalah (X4) & $\begin{array}{l}\text { - Mencegah dan menimialisir munculnya } \\
\text { masalah dan keluhan } \\
\text { - Bersikap terbuka dalam menyelesaikan } \\
\text { masalah } \\
\text { - Mampu memberi solusi }\end{array}$ & $\begin{array}{l}\text { Cukup } \\
\text { Efektif }\end{array}$ \\
\hline 5 & Loyalitas $(\mathrm{Y})$ & $\begin{array}{l}\text { - Ingin terus menjadi nasabah pada Bank } \\
\text { ini } \\
\text { Menceritakan hal yang positif tentang } \\
\text { Bank ini kepada orang lain. } \\
\text { - Memilih Bank ini dalam melakukan } \\
\text { kegiatan perbankannya. } \\
\text { - Merekomendasikan Bank ini kepada } \\
\text { orang lain. }\end{array}$ & Tinggi \\
\hline
\end{tabular}

\subsection{Hasil Uji Analisis Regresi Linear Berganda dan interpretasi}

Coefficients $^{a}$

\begin{tabular}{|c|c|c|c|c|c|c|c|}
\hline \multirow[b]{2}{*}{ Model } & \multicolumn{2}{|c|}{$\begin{array}{l}\text { Unstandardized } \\
\text { Coefficients }\end{array}$} & \multirow{2}{*}{\begin{tabular}{|c|}
$\begin{array}{c}\text { Standardized } \\
\text { Coefficients }\end{array}$ \\
Beta
\end{tabular}} & \multirow[b]{2}{*}{$\mathrm{T}$} & \multirow[b]{2}{*}{ Sig. } & \multicolumn{2}{|c|}{$\begin{array}{c}\text { Collinearity } \\
\text { Statistics }\end{array}$} \\
\hline & B & Std. Error & & & & Tolerance & VIF \\
\hline (Constant) & -.395 & .155 & & -2.550 & .012 & & \\
\hline X1 (Kepercayaan) & .138 & .030 & .129 & 4.531 & .000 & 910 & 1.099 \\
\hline X2 (Komitmen) & .126 & .038 & .110 & 3.305 & .001 & .675 & 1.482 \\
\hline X3 (Komunikasi) & .582 & .055 & .608 & 10.545 & .000 & .223 & 4.489 \\
\hline X4 (Penanganan Masalah) & .250 & .054 & .279 & 4.646 & .000 & .206 & 4.862 \\
\hline
\end{tabular}

a. DependentVariable: $Y$

$$
Y=0,395+0,138\left(X_{1}\right)+0,126\left(X_{2}\right)+0,582\left(X_{3)}+0,250\left(X_{4}\right)\right.
$$




\subsection{Hasil Uji Hipotesis}

\begin{tabular}{|l|l|l|l|}
\hline \multicolumn{1}{|c|}{ Model } & \multicolumn{1}{|c|}{ T } & \multicolumn{1}{|c|}{ Sig } & \multicolumn{1}{c|}{$\begin{array}{c}\text { Ket. } \\
\boldsymbol{\alpha}(\mathbf{0 , 0 5})\end{array}$} \\
\hline Kepercayaan (X1) & 4.531 & .000 & Pengaruh Signifikan \\
\hline Komitmen (X2) & 3.305 & .001 & Pengaruh Signifikan \\
\hline Komunikasi (X3) & 10.545 & .000 & Pengaruh Signifikan \\
\hline Penanganan Masalah (X4) & 4.646 & .000 & Pengaruh Signifikan
\end{tabular}

Berdasarkan tabel tersebut terlihat bahwa hasil pengujian variabel Kepercayaan menunjukkan nilai $t_{\text {hitung }}$ sebesar 4,531 yang lebih besar dari nilai ttabel $(\mathrm{t}(\mathrm{a} / 2)(\mathrm{n}-2)=\mathrm{t}$ $(0,05 / 2)(100-2)=t(0,025,98)=t$ tabel 1,984 (Sumber : lampiran 4). Hal ini menyatakan bahwa hipotesis awal (H0) ditolak dan menerima hipotesis alternatif (Ha). Dengan demikian dapat disimpulkan bahwa kepercayaan berpengaruh secara positif dan signifikan terhadap Loyalitas Nasabah. Kedua variabel ini saling terkait artinya Relationship marketing pada variabel Kepercayaan mampu mempengaruhi tingkat Loyalitas Nasabah dimana semakin tinggi kepercayaan nasabah pada perusahaan akan meningkatkan Loyalitas Nasabah terhadap Perusahaan tersebut.

Hasil pengujian variabel Komitmen menunjukkan nilai $t$ hitung sebesar3,305 dan nilai ttabel $(\mathrm{t}(\mathrm{a} / 2)(\mathrm{n}-2)=\mathrm{t}(0,05 / 2)(100-2)=\mathrm{t}(0,025,98)=$ tabel 1,984. Hal ini menunjukkan bahwa thitung $>$ dari ttabel yang menyatakan bahwa hipotesis awal (H0) ditolak dan menerima hipotesis alternatif (Ha). Dengan demikian dapat disimpulkan bahwa Komitmen berpengaruh secara positif dan signifikan terhadap Loyalitas Nasabah. Variabel Relationship Marketing pada Komitmen saling terkait dengan variabel terikat artinya mampu mempengaruhi tingkat Loyalitas Nasabah dimana semakin tinggi Komitmen nasabah terhadap perusahaan maka akan meningkatkan Loyalitas Nasabah terhadap Perusahaan tersebut.

Nilai $t_{\text {hitung }}$ sebesar 10,545 yang lebih besar dari nilai ttabel $(t(a / 2)(n-2)=t(0,05 / 2)(100-$ $2)=t(0,025,98)=$ ttabel 1,984 (Sumber : lampiran 4). Hal ini menyatakan bahwa hipotesis awal (H0) ditolak dan menerima hipotesis alternatif (Ha). Dengan demikian dapat disimpulkan bahwa Komunikasi berpengaruh secara positif dan signifikan terhadap Loyalitas Nasabah. Kedua variabel ini saling terkait artinya variabel Relationship marketing pada Komunikasi mampu mempengaruhi tingkat Loyalitas Nasabah dimana semakin baik dan eratnya Komunikasi yang diciptakan perusahaan kepada nasabah maka akan meningkatkan Loyalitas Nasabah terhadap Perusahaan tersebut.

Hasil pengujian variabel Penanganan Masalah menunjukkan nilai $t$ hitung sebesar 4,646 yang lebih besar dari nilai ttabel $(\mathrm{t}(\mathrm{a} / 2)(\mathrm{n}-2)=\mathrm{t}(0,05 / 2)(100-2)=\mathrm{t}(0,025,98)=\mathrm{ttabel} 1,984$ (Sumber : lampiran 4). Hal ini yang menyatakan bahwa hipotesis awal (H0) ditolak dan menerima hipotesis alternatif (Ha). Dengan demikian dapat disimpulkan bahwa Penanganan Masalah berpengaruh secara positif dan signifikan terhadap Loyalitas Nasabah. Variabel Relationship Marketing pada Penanganan Masalah saling terkait dengan variabel terikat artinya mampu mempengaruhi tingkat Loyalitas Nasabah dimana semakin baik Penanganan 
suatu masalah dari perusahaan maka akan meningkatkan Loyalitas Nasabah terhadap Perusahaan tersebut.

Pada Penelitian ini ditemukan bahwa Kepercayaan (Trust) berpengaruh terhadap loyalitas nasabah pada PT Bank Perkreditan Rakyat Segara Anak Kencana Cabang Mataram. Bank Perkreditan Rakyat ini mengaplikasikan elemen kepercayaan dengan menciptakan dan menjamin dalam memberikan rasa aman bagi nasabah dalam melakukan segala kegiatan perbankan. Pengetahuan petugas dalam menguasai setiap produk perbankan memiliki andil besar dalam menmberikan rasa aman dalam setiap kegiatan perbankan. Dengan pengetahuan tersebut akan mengasah kemampuan petugas untuk melakukan tindakan preventif jika diperlukan dalam menjaga rasa aman nasabah terhadap Bank Perkreditan yang dipilih ini. Selain itu pelayanan yang berkualitas disajikan oleh Bank Perkreditan Rakyat Segara Anak Kencana Cabang Mataram memiliki dan melatih karyawan atau petugas agar memiliki dengan tingkat pengetahuan dan pengalaman dalam menghadapi nasabah. Menjadikan nasabah memiliki kemauan untuk menceritakan hal yang baik (Word of Mouth) kepada orang lain tentang perbankan ini tentunya harus dimulai dengan diterimanya pelayanan yang baik dan istimewa dari Bank tersebut. Sikap cepat dan tepat atau responsiveness yang dimiliki petugas merupakan salah satu bentuk sikap peduli yang akan mampu menciptakan word of mouth positif dari nasabah kepada orang lain yang ditemuinya ketika berbicara mengenai Bank Perkreditan.

Variabel komitmen memiliki keterkaitan yang sangat erat dengan variabel kepercayaan dalam mewujudkan strategi Relationship Marketing. Kedua variabel ini saling berintegrasi satu sama lain guna menciptakan sebuah hubungan bisnis jangka panjang. Bank Perkreditan Rakyat Segara Anak Kencana Cabang Mataram memberikan dalam bentuk layanan produk yang berkualitas disesuaikan dengan kebutuhan dari nasabah, misalnya dalam proses pengajuan kredit akan diberikan tentang informasi detail pembayaran atau anagsuran yang dinginkan sesuai kemampuan dari nasabah. Dalam hal memenuhi janji tentunya akan terjadi koordinasi internal antara Bank Perkreditan Rakyat Segara Anak Kencana Cabang Mataram dengan petugas yang berhubungan lebih intens dengan nasabah sehingga dalam penyampain informasi produk dan pelayanan perbankan tidak terlepas dari visi misi yang ditawakan baik kepada nasabah yang sudah lama ataupun calon nasabah.

Informasi yang disampaikan secara detail kepada nasabah baik dalam bentuk lisan atau tertulis, secara langsung atau tidak langsung sudah menjadi salah satu faktor yang berperan penting dalam hal meningkatkan Loyalitas Nasabah pada Bank Perkreditan Rakyat Segara Anak Kencana Cabang Mataram. Komunikasi yang dilakukan dalam hal menyampaikan produk-produk yang ada pada Bank Perkreditan Rakyat Segara Anak Kencana Cabang Mataram dilakukan melalui brosur-brosur atau leaflet yang berisikan informasi yang dibutuhkan oleh nasabah dalam melakukan kegiatan perbankannnya pada Bank Perkreditan ini. Mengenai cara komunikasi dalam hal kaitan dengan penyampaian informasi dapat dilakukan secara langsung atau bertatap muka langsung dengan nasabah. Menjadi sebuah kegiatan keseharian yang dilakukan bagi petugas marketing untuk bertemu secara langsung dengan nasabah, untuk itu dalam kondisi tersebut, dapat dimanfaatkan dengan melakukan promosi terhadap produk perbankan yang dimiliki tentunya dengan penggunaan bahasa yang baik dan santun guna mencegah timbulnya kesalahpahaman ketika menafsirkan informasi. Dengan karakteristik responden yang berjumlah $54 \%$ adalah sekolah 
menegah atas, tentunya penyampaian informasi perlu dipertimbangkan menggunakan bahasa yang jelas, lugas dan mudah dimengerti.

Bank Perkreditan Rakyat Segara Anak Kencana Cabang Mataram dalam kegiatan pelayanan perbankan dalam kaitan penanganan masalah adalah dengan meminimalisir munculnya potensi yang bisa menyebabkan masalah. Pengetahuan produk dan penggunaan bahasa yang ramah serta pelayanan yang berkualitas dan istimewa dari pihak Bank Perkreditan merupakan salah satu hal yang berperan penting. Jika memang pada akhirnya masalah kemudian timbul antara nasabah dengan pihak Bank Perkreditan Rakyat Segara Anak Kencana Cabang Mataram, maka sikap terbuka dalam menyampaikan informasi ditambah dengan membuka diskusi sehingga diperoleh solusi yang baik dan sesuai dengan standar operasional yang berlaku pada Bank Perkreditan Rakyat Segara Anak Kencana Cabang Mataram

\section{KESIMPULAN DAN SARAN}

Variabel Relationship Marketing yang terdiri dari Kepercayaan (Trust), Komitmn, Komunikasi, dan Penanganan Masalah berpengaruh positif terhadap Loyalitas Nasabah pada PT Bank Perkreditan Rakyat Segara Anak Kencana Cabang Mataram.Dalam usaha meningkatkan rasa kepercayaan nasabah dalam kaitan dengan Loyalitas Nasabah pada indikator kemampuan permodalan dan sikap peduli masih berada pada kategori sedang, perlu dilakukan perbaikan strategi yang berkaitan dengan dua hal tersebut. Kemampuan permodalan dapat disosialisasikan oleh pihak Bank Perkreditan kepada nasabah pada pelayanan yang dilakukan pada saat bertemu secara langsung atau secara tatap muka dan biasanya dilakukan oleh petugas yang banyak berada dilapangan. Tingkat pengetahuan yang dimiliki oleh pertugas pihak Perbankan megenai produk dan semua informasi detail mengenai itu akan mudah disampaikan kepada nasabah. Untuk memulai munculnya sikap peduli dapat dilakukan dengan memberikan "penghargaan" atau gift kepada nasabah yang sudah meluangkan waktunya bersama bank perkreditan mulai dari 5 tahun sampai seterusnya.

Dalam usaha untuk meningkatkan kualitas produk yang dimiliki oleh pihak Bank Perkreditan Rakyat Segara Anak Kencana Cabang Mataram dibarengin dengan usaha "empower your empolyees". Menempatkan karyawan yang berdedikasi tinggi pada Bank Perkreditan Rakyat Segara Anak Kencana menyangkut dengan kemampuan karyawan dalam mengusai pengetahuan tentang produk-produk yang ada, sehingga kepercayaan dirinya ini dalam menjelaskan segala keunggulan produk tersebut dapat berimbas kepada kepercayaan diri nasabah saat memperoleh informasi tersebut. Tetap konsisten pada layanan dan produk yang dimiliki serta memperbaiki setiap kekurangan dan keluhan dari nasabah menjadi salah satu kunci untuk mempertahankan kualitas produk.

Dalam hal Penanganan Masalah, Bank Perkreditan Rakyat Segara Anak Kencana Cabang Mataram mampu mengenali setiap potensi keluhan atau masalah yang dapat muncul serta mampu memberikan solusi yang cepat dan realistis terhadap keluhan atau masalah dari nasabahnya. Informasi yang terdapat dalam Bank Perkreditan ini harus diberikan atau disampaikan secara berkala kepada nasabah. Mendengarkan setiap keluhan akan menjadi hal yang begitu berkesan bagi nasabah disamping solusi nyata yang diperlukan. 


\section{DAFTAR PUSTAKA}

Abdullah, Fariz Muhammad, (2014). Impact of Relationship Marketing Tactis (RMT's) and Relationship Quality on Customer Loyalty : A Study Within the Malaysian Mobile Telecommunication Industry. Procedia - Social and Behavioural Sciences 130 : 371- 378

Abtin, Abdolaziz, Mostafa Pouramiri, (2016). The Impact of Relationship marketing on Customer Loyalty enhancement ( Case Study : Kerman Iran Insurance company). Marketing and Branding Resesrach 3 ( 2016) : 41 - 49.

Adjei, Mavis T, Melissa N.Clark, (2010). Relationship marketing in A B2C Context : The moderating role of personality traits. Journal of Retailing and Consumer Services 17 (2010) 73-79.

Bilgihan, Anil dan Milos Bujisic,(2014). The effect of website features in online relationship marketing : A case of online hotel booking. Electronic Commerce Resesarch and Applications (2014):1567-4223.

Bressan,Federicca (2014). Get off to a good start. International Relationship Marketing in Emerging Markets. Procedia - Social and Behavioural Sciences : 1230 - 1239.

Cravens, David W. (1996).Pemasaran Strategis. Jakarta : Penerbit Erlangga

Dick, Alan S, Kunal Basu. (1994). Customer Loyalty : Toward an Integrated Conceptual Framework. Journal of the Academy of Marketing Science, Vol 22, No 2 : 99-113.

Garland, Ron, Philip Gendall (2004). Testing Dick and Basu's Customer Loyalty Model. Australasian Marketing Journal 12 (3), 2004.

Griffin Jill (2005). Customer loyalty, How to earn it now to keep it. Singapore:lexington books

Hurriyati, Ratih, 2010. Bauran Pemasaran dan Loyalitas Konsumen. Bandung : Alfabeta.

Husnain, Mudassir, Waheed Akhtar, (2015). Relationship Marketing and Customer Loyalty : Evidence from Banking Sector in Pakistan. Global Journal Of Management and Bussiness Resesarch : E Marketing Vo 15 Issue 10 ISSN : 2249 - 4588 : 1 - 9.

Hyun, Sunghyup Sean, Richard R.Perdue (2017). Understanding the dimensions of customer relationship in thr hotel and restaurant industries. Intenational Journal of Hospitality Management 64 (2017) 73-84.

Jati, Kasuma (2016). Determinant of Micro Enterprise Owner's Loyalty Towards Their Favourite Bank. Procedia - Social and Behavioural Sciences 224 : 301-307.

Jumaev, Mukhiddin, Dileep Kumar, Jalal Hanaysa, (2012). Impact of Relationship Marketing on Customer Loyalty in the Banking Sector. Far East Journal of Psychology and Bussiness, Vol 6 No 3 March 2012.

Karjaluoto, Heikki, Chanaka Jayawardhena, Matti Leppaniemi, Minna Pihlstrom, (2012). How value and trust influence loyalty in wireless telecommunication industry. Telecommunication Policy 36 (2012) 636-649.

Keegan, Warren J, 2003. Manajemen Pemasaran Global.Jakarta : PT Intan Sejati.

Kotler, Philip. 2002. Manajemen Pemasaran, Analisa perencanaan, Implementasi dan control, Edisi Kesembilan, Jilid 1 dan jilid 2, Jakarta, Prehalindo, alih bahasa oleh Hendra Teguh S.E.,A.K., dan Ronny A. Rusli, S.E.

Lee, Liane W.Y. Yiming Tang,Leslie S.C Yip, Piyush Sharma (2017). Managing customer relationship in the emerging markets - guanxi as a driver of Chinese customer loyalty. Journal of Business Research (2017).www.elsevier.com/locate/jbusres.

Malhotra, Naresh K. 2009. Riset Pemasaan Jilid I. Jakarta : Indeks Kelompok Gramedia. 
Mckercher, Bob, Basak Denisci-Guillet, Erica Ng (2012). Rethingking Loyalty. Annals of Tourism Research, Vol. 39, No. 2, pp. 708-734, 2012. www.elsevier.com/locate/atoures.

Mulyono, Sri. 2003. Statistika Untuk Ekonomi Edisi Kedua. Jakarta : Lembaga Penerbit Fakultas Ekonomi Universitas Indonesia.

Ndubisi, Nelson Oly, (2007). Relationship Marketing and Customer Loyalty. Marketing Intelligence \& Planning, Vol 25 No 1, 2007: 98-106.(2011) 109-117.

Ndubisi, Nelson Oly (2011). Conflict handling,trust, and commitment in outsourcing relationship : A Chinese and Indians study. Industrial Marketing Management 40

O'Malley, Lisa, Andrea Prothero, (2004). Beyond the frills of relationship marketing. Journal of Business Research 57 (2004) 1286- 1294.

Riasi, Arash, Azarnoush Ansari (2016). Modelling and evaluating customer loyalty using neiral networks : Evidence from startup insurance companies. ScienceDirect by Elsivier,Future Bussiness Journal 2 (2016) 15-30.

Schiffman, Leon G, Leslie Lazar Kanuk ,2008. Perilaku Konsumen. Jakarta : PT Indeks.

Sekaran, Uma, 2006. Research Methods for Bussiness. Buku 1 Edisi 2, Jakarta : Salemba Empat. Sekaran,Uma, 2006. Research Methods for Bussiness. Buku 2 Edisi 4, Jakarta : Salemba Empat.

Shaalan, Ahmed S, Jon Reast, Debra Jhonson, Marwa E.Tourky (20130. East meets west : Toward theoretical model linking guanxi and relationship marketing. Jounal of Business Research 66 (2013) 2515-2521.

Sukirno, Sadono ,2011. Pengantar Bisnis.Jakarta : Kencana Prenada Media Grup.

Sulhaini. 2014. Relationship Marketing. Mataram University Press.

Sunyoto, Danang,2013. Teori, Kuesioner, dan Analisis Data untuk Pemasaran dan Perilaku Konsumen. Yogyakarta : Graha Ilmu.

Semuel, Hatane., (2010). Customer Relationship Marketing Pengaruhnya Terhadap Kepercayaan dan Loyalitas Perbankan Nasional, Jurnal Manajemen Pemasaran, Vol 7, No 1,2012 : 33-41.

Setyawan, P., (2013) Pengaruh Kepercayaan, Komitmen, Harga Dan Keluhan Pelanggan Terhadap Loyalitas Pelanggan Kantor Pos Surakarta, Abstrak.

Silva, Francisco Jose Casio,Maria Angeles Camacho,Manuela Vega Vasquez, Beatrice Palacios Florencio,(2016).Value co-cretaion and customer loyalty. Journal of Business Reasearch 69 (2016) 1621-1625.

Silalahi, Ulber. (2010). Metode Penelitian Sosial. Jakarta: Refika Aditama.

Sugiyono, 2008. Metode Penelitian Bisnis. Edisi keduabelas. Bandung: Alfabeta (2009). Metode Penelitian Bisnis. CV.Alfabeta, Bandung. (2012). Metode Penelitian Kuantitatif Kualitatif dan RED. CV.Alfabeta, Bandung.

Sui, Jun Jian dan Seyhmus Baloglu (2003). The Role Emotional Commitment in Relationship Marketing : An Empirical Investigation Of A Loyalty Model for Casinos. Journal of Hospitality and Tourism Research, Vol 27,No.4, Noovember 2003, 470-489.

Sumbawati, Novi Kadewi. (2014). Analisis Pengaruh Relationship Marketing Pengusaha Ternak Terhadap Kinerja Pemasaran di Kabupaten Sumbawa. Tesis. Universitas Mataram

Suparwata, Dewa Made. (2016). Analisis Pengaruh Customer Relationship Marketing Terhadap Loyalitas Nasabah pada PT SinarMas Kantor Cabang Mataram. Tesis. Universitas Mataram. 
Taylor, James R and Thomas C.Kinner., Riset Pemasaran. Edisi Ketiga. Jilid I. Jakarta : Penerbit Erlangga.

Tjiptono, F., 2000, Manajemen Jasa. Yogyakarta : Penerbit Andi

Yoganathan, Dhanushantini, Charles Jebarajakirthy, Paramaporn Thaicon, (2015). The Influence of relationship marketing orientation on brand equity in banks. Journal of Retailing and Consumer Services 26 (2015) 14-22. 